\title{
Pemanfaatan Google Form Sebagai Pendaftaran TOEFL (Test of English as a Foreign Language) secara Online
}

\author{
Indri Handayani ${ }^{1)}$, Qurotul Aini' ${ }^{2)}$, Novi Cholisoh ${ }^{3)}$, Iim Ilmiah Agustina ${ }^{4)}$ \\ 1,2,3,4) STMIK Raharja \\ Jl.Jendral Sudirman No.40 Modern Cikokol - Tangerang 15117 \\ Email: indri@ raharja.info $^{1)}$, aini@ raharja.info $^{2)}$, novi@ raharja.info $^{3)}$, iim@ raharja.info $^{4)}$
}

\begin{abstract}
Abstrak
Google form adalah sebuah fitur dari google untuk mengirimkan formulir pendaftaran, adapun manfaat dari google form ini yaitu untuk distribusi dan tabulasi online real-time, real-time collaboration 50 orang dapat bekerja dalam satu berkas dalam satu waktu dan setiap perubahan disimpan secara otomatis.Dan aman menyimpan berkas penting atau tugas kuliah tidak takut hilang atau rusak karena terkena virus. Dari beberapa keuntungan atau pemanfaatan yang terdpat pada google form inilah penulis tertarik untuk mengambil judul jurnal yang mengambil tema pemanfaatan gooogle form sebagai pendaftaran TOEFL ( Test Of Engkish as a Foreign Language) Secara Online. formulir kuesioner online atau merencanakan acara. Secara keseluruhan google form adalah sebuah alat untuk mengumpulkan informasi dengan mudah dan efisien, proses registrasi TOEFL masih dilakukan secara konvensional. proses registrasi secara konvensional adalah data pendaftar yang rentan hilang dan rusak, permasalahan lain yang dihadapi juga tidak adanya sebuah prosedur mengenai alur registrasi TOEFL sehingga umumnya calon pendaftar hanya mendapatkan informasi dari orang ke orang. Hasil yang diperoleh dari implementasi sistem form registrasi TOEFL ini dapat digunakan tanpa perlu login email terlebih dahulu lalu setelah pendaftar mensubmit form maka akan mendapatkan email notifikasi data submit form secara otomatis sehingga pendaftar dapat mengetahui bahwa data yang diberikan telah valid dan diterima oleh admin.
\end{abstract}

Kata kunci -TOEFL, Rinfo Form, Registrasi.

\section{Pendahuluan}

Kemajuan Teknologi Informasi sangat berpengaruh dan memberikan manfaat yang luar biasa bagi bidang pendidikan, Seperti yang telah kita ketahui sebelumnya bahwa teknologi informasi memiliki peranan yang penting dan sangat mempengaruhi sistem pendidikan yang berjalan. Memenuhi kebutuhan masyarakat akan informasi yang cepat, tepat, dan akurat merupakan tantangan tersendiri bagi suatu instansi pendidikan baik formal maupun non formal. Perguruan Tinggi Raharja merupakan salah satu instansi pendidikan yang memiliki konsentrasi dalam bidang teknologi informasi dan komputer, untuk itu Perguruan Tinggi Raharja senantiasa terus berinovasi dalam menciptakan program ataupun sistem-sistem yang dapat digunakan untuk mendukung kegiatan perkuliahan.
Perguruan Tinggi Raharja memiliki program yang bernama RCEP. RCEP merupakan pengertian dari Raharja Certified English Proficiency yaitu berupa paket jaminan mutu kemampuan berbahasa inggris pribadi raharja yang umumnya terdiri dari perkuliahan, training, test, dan sertifikasi. RCEP (Raharja Certified English Proficiency) juga mendukung TOEFL (Test Of English Foreign Language).

Registrasi biasa disebut juga dengan pendaftaran, registrasi sendiri terbagi menjadi dua yaitu registrasi manual yang masih menggunakan formulir pendaftaran dan dilakukan secara tertulis, serta registrasi online yang dilakukan dengan menggunakan formulir pendaftaran online tanpa perlu dilakukan dengan cara tertulis. Proses registrasi yang berjalan saat ini terdapat banyak kekurangan seperti pada saat pribadi raharja ataupun masyarakat umum ingin melakukan pendaftaran karena siapapun yang ingin melakukan pendaftaran harus datang langsung dan menemui ketua pelaksana serta memberikan fotocopy bukti pembayaran, dimana hal ini sangat memakan banyak sekali waktu dan biaya.

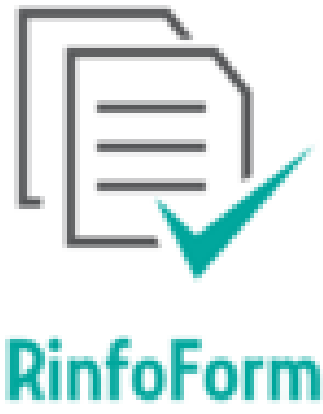

Gambar 1. Rinfo Form

Sumber : (http://timur.ilearning.me/2016/04/18/hasilvoting-logo-rinfo-form/)

\section{Metode Penelitian}

Dalam sebuah proses penulisan karya ilmiah dibutuhkan adanya metode penelitian yang berguna untuk mencapai tujuan dan mendapatkan informasi yang akurat dan terpercaya yang dibutuhkan oleh penulis untuk melakukan beberapa tahapan dalam penelitian. Dalam penelitian ini penulis menggunakan beberapa metode penelitian diantaranya metode pengumpulan data yang terdiri dari observasi, wawancara, serta metode studi pustaka. 


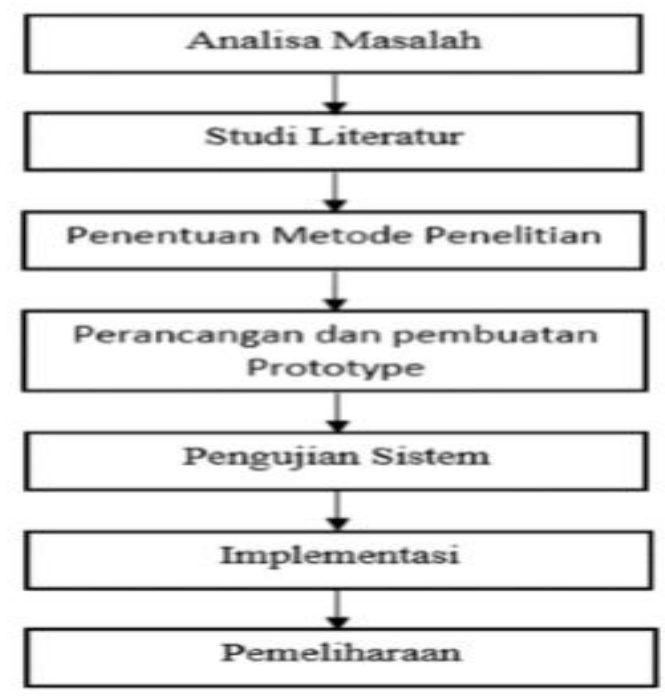

Gambar 2. Tahapan Penelitian

Keterangan :

1. Analisa Masalah, melakukan Analisa terhadap permasalahan yang dihadapi pada sistem yang sedang berjalan.

2. Studi Literatur, yaitu dengan mencari, membaca, dan memahami berbagai sumber referensi penelitian sejenis yang berasal dari buku dan jurnal-jurnal sebelumnya yang dapat dijadikan landasan dalam penelitian.

3. Penentuan Metode Penelitian, menentukan metodemetode penelitian apa saja yang relevan dengan penelitian yang sedang dilakukan, dengan memilih metode penelitian menggunakan Google Form atau Rinfo Form guna membuat program registrasi TOEFL secara online.

4. Perancangan dan Pembuatan Prototype, setelah membuat konsep rancangan dan metode penelitian langkah selanjutnya adalah membuat prototype program agar Perancangan dapat lebih mudah dipahami.

5. Pengujian Sistem, adalah pengujian sistem yang dengan tujuan untuk menampilkan keunggulan dari sistem lama dan mengurangi kesalahan yang ditimbulkan dari sistem yang baru dan bertujuan untuk mengevaluasi apakah sistem sudah sesuai dengan harapan user.

6. Implementasi, apabila sistem telah sesuai dengan yang diharapkan user maka langkah selanjutnya adalah proses implementasi agar sistem dapat benarbenar digunakan dan direalisasikan dengan baik.

7. Pemeliharaan, Tahapan terakhir adalah memelihara dan menjaga agar sistem yang telah diimplementasikan dapat terawat dengan baik.

Berikut ini adalah daftar literature review yang digunakan dalam penelitian ini:

1. Penelitian yang dilakukan oleh Indri Handayani, Herrafika Kusumahati, dan Alpiah Nurul Badriah mengenai Pemanfaatan Google Spreadsheet Sebagai Media Pembuatan Dashboard. Dalam penelitian tersebut penulis membahas mengenai CCIT journal yang masih bersifat tradisional, sehingga penulis harus datang ke Perguruan Tinggi Raharja dan menyerahkan hasil penulisannya baik softcopy maupun hardcopy kepada admin sehingga memakan banyak waktu dan tenaga. Karena itu, diperlukan adanya sistem E-Journal dengan memanfaatkan iMe (iLearning Media) dan Rinfo (Raharja.Info) agar sistem penerimaan jurnal dapat berjalan dengan efektif dan efisien.

2. Penelitian yang dilakukan oleh Eli Pujiastuti dengan judul Perancangan Sistem Informasi Pendaftaran Mahasiswa Aktif Kembali di STMIK Amikom Yogyakarta. Yang membahas perihal Perguruan Tinggi seperti STMIK Amikom Yogyakarta telah mengembangkan sistem dan infrastruktur untuk mendukung proses akademik, proses pemberian NIM mahasiswa baru yang melakukan pendaftaran masih dilakukan secara manual menggunakan Microsoft Xxcel dan Microsoft Word besarnya kemungkinan kesalahan, lamanya waktu tunggu pada sistem manual menjadi masalah yang mendasari peneliti membuat sebuah Perancangan sistem informasi pendaftaran mahasiswa aktif kembali di STMIK AMIKOM Yogyakarta. Hasil dari penelitian ini adalah dokumen untuk pengembangan sistem berikutnya, yang sebelumnya mengatur rumus secara manual menggunakan Microsoft Excel kini otomatis dihitung oleh sistem dan Sistem Informasi.

3. Penelitian yang dilakukan oleh Indah Yuwelina Muntaruk, Rudy Steven Wenas, Arrazil Hassan Jan dengan judul Analisis Pengaruh Budaya Organisasi Disiplin Kerja Dan Komunikasi Terhadap Kinerja Karyawan (Studi Kasus Di Pt. Angkasa Pura 1 (Persero) Cabang Bandara Internasional Sam Ratulangi Manado). Dalam penelitian ini membahas untuk mengetahui pengaruh budaya organisasi, disiplin kerja dan komunikasi terhadap kinerja karyawan. Metode penelitian menggunakan metode penelitian asosiatif dengan teknik analisis regresi linear berganda. Yang menggunakan Google form sebagai media. Pada penelitian ini menggunakan data yang di dapat dari PT. Angkasa Pura 1 (Persero), penelitian dengan menggunakan kuesioner online (google form). Data sekunder diperoleh dari studi pustaka, buku-buku literature serta penelitian sebelumnya yang berkaitan dengan permasalahan dalam penelitian ini.

4. Penelitian yang dilakukan oleh Anggi Agustin, Hassan Suryono, Erna Yuliandari dengan judul Teknik Penilaian Diri Berbasis Google Form Pada Mata Pelajaran Pendidikan Pancasila Dan Kewarganegaraan. Penelitian ini mebahas tentang penilaian diri berbasis Google Form yang mampu mengembangkan karakter siswa yang meliputi tanggungjawab moral terhadap dirinya sendiri, disiplin diri dan penghargaan terhadap harkat dan martabat manusia pada setiap individu.

5. Penelitian yang dilakukan oleh Kartika Gianina Tileng dengan judul "Penerapan Technology 
Acceptance Model pada Aplikasi Edmodo di Universitas Ciputra Surabaya menggunakan Analisis Jalur". Dalam penelitian ini peneliti ingin melihat bagaimana TAM (Technology Acceptance Model) dari Edmodo yang sudah diterapkan dengan metode Analisis Jalur (Path Analysis) dengan menggunakan Google form sebagai form kuesioner dan telah mendapat respon.

6. Penelitian yang dilakukan oleh Untung Rahardja, Khanna Tiara, dan Ray Indra Taufik Wijaya dengan judul "Penerapan Rinfo Sebagai Media Pendukung Untuk Proses Pembelajaran Pada Perguruan Tinggi Raharja”. Penelitian ini menunjukkan bahwa Rinfo adalah gmail yang diadaptasi dari Google platform dengan ciri khas raharja.info sebagai domainnya yang terhubung dengan alat penunjang pembelajaran lainnya, seperti Docs, Drive, Sites dan alat penunjang lainnya.

7. Penelitian yang dilakukan oleh Muhammad Rizal Fauzi dengan judul "Penggunaan Google Form Sebagai Alat Evaluasi Pembelajaran Pada Mata Pelajaran Bahasa Indonesia: Studi Deskriptif Analitis pada Kelas VIII di Sekolah Menengah Pertama Negeri 1 Lembang". Penelitian ini membahas tentang penggunaan Google form sebagai alat evaluasi pembelajaran Bahasa Indonesia mulai dari tahap perencanaan, kesiapan sarana dan prasarana, pengembangan Google form, hingga tahap implementasi menggunakan Google form dalam evaluasi belajar.

\section{Hasil Dan Pembahasan}

\subsection{Analisa Permasalahan}

Bagi Perguruan Tinggi Raharja sendiri, saat ini TOEFL (Test Of English Foreign Language) telah resmi dijadikan persyaratan untuk dapat mengikuti sidang TA/Skripsi dimana seluruh mahasiswa yang ingin mengikuti sidang TA/Skripsi diwajibkan untuk memiliki sertifikat TOEFL (Test Of English Foreign Language) dengan skor minimal 450. Dalam hal ini, registrasi merupakan hal yang paling utama untuk menunjang proses training maupun tes serta sertifikasi TOEFL (Test Of English Foreign Language).

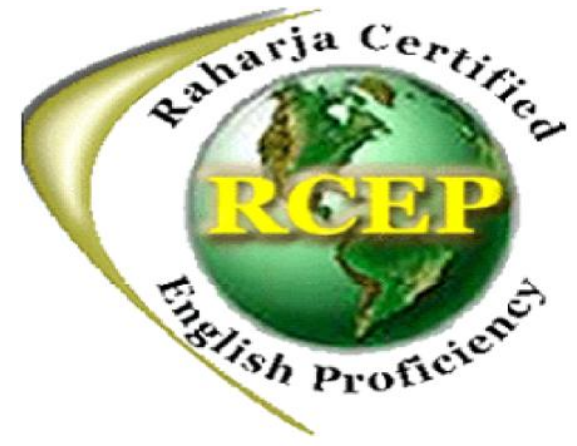

Gambar 3. Logo RCEP

Sumber : http://rcep.ilearning.me/
Registrasi sendiri terbagi menjadi dua yaitu registrasi manual yang masih menggunakan formulir pendaftaran dan dilakukan secara tertulis, serta registrasi online yang dilakukan dengan menggunakan formulir pendaftaran online tanpa perlu dilakukan dengan cara tertulis. Namun, pada sistem proses registrasi yang berjalan terdapat banyak kekurangan seperti pada saat pribadi raharja ataupun masyarakat umum ingin melakukan pendaftaran karena siapapun yang ingin melakukan pendaftaran harus datang langsung dan menemui ketua pelaksana serta memberikan fotocopy bukti pembayaran, dimana hal ini sangat memakan banyak sekali waktu dan biaya.

Mahasiswa yang sudah melakukan pembayaran registrasi TOEFL harus mem-fotocopy kwitansi pembayaran yang kemudian diberikan sebagai data diri yang digunakan guna mengumpulkan informasi mengenai pendaftar. Informasi data diri pendaftar yang hanya dapat dilihat melalui fotocopy kwitansi ini tentunya sangat tidak akurat, dan dikhawatirkan apabila suatu saat fotocopy kwitansi pembayaran tersebut hilang maka ketua pelaksana tidak memiliki data lain yang dapat digunakan untuk informasi mengenai pendaftar atau calon peserta training dan tes TOEFL, hal ini tentunya sangat tidak efektif dan efisien.

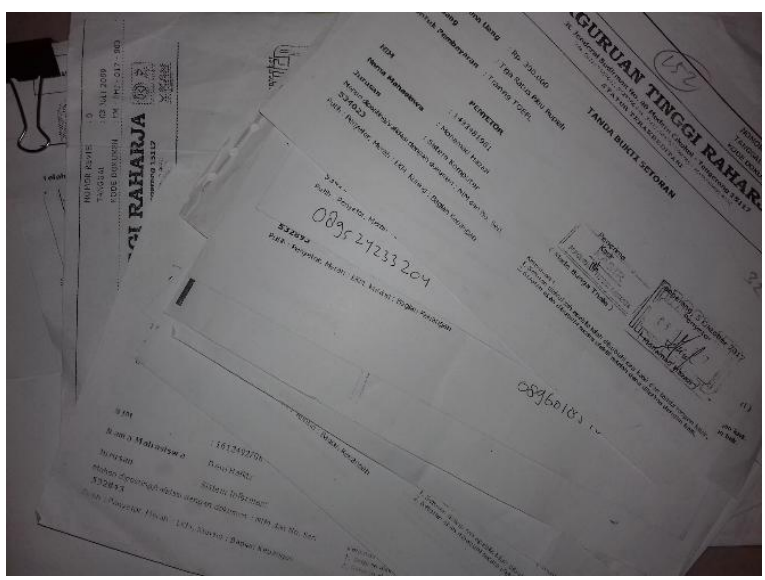

Gambar 4. Fotocopy kwitansi pembayaran TOEFL

\subsection{Pemecahan Masalah}

Berdasarkan masalah yang terdapat pada latar belakang penelitian yang diuraikan dalam bahasan sebelumnya, Peneliti merasa perlu mengembangkan sistem Official Site RCEP agar dapat dijadikan wadah untuk mendukung proses registrasi toefl secara online. Sehingga, Penelitian ini berfokus pada proses registrasi TOEFL (Test Of English Foreign Language) secara online dan dokumentasi rekap score peserta training dan tes TOEFL (Test Of English Foreign Language) yang berlangsung di lingkungan Perguruan Tinggi Raharja. 


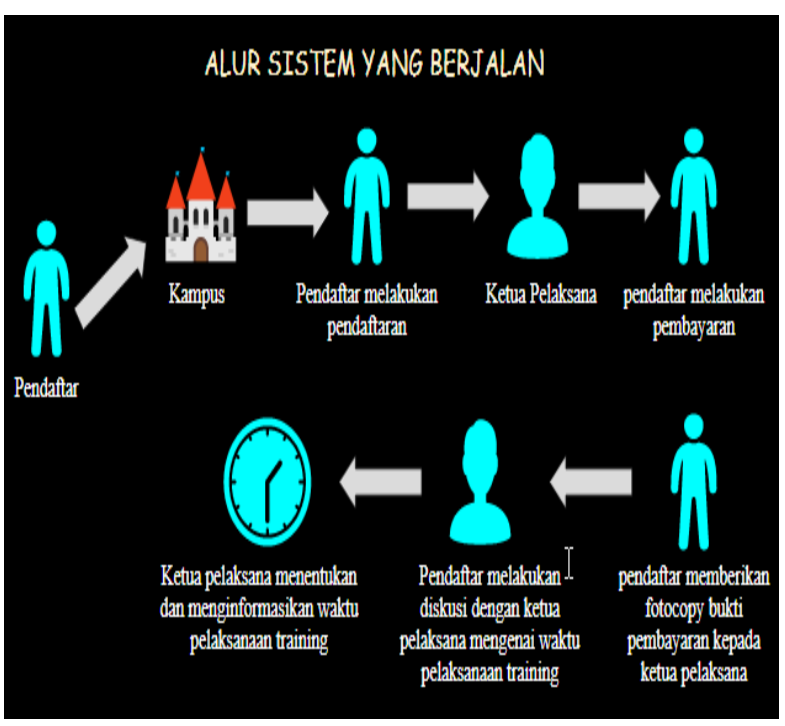

Gambar 5. Alur Sistem Yang Berjalan

Gambar di atas merupakan gambaran dari alur sistem registrasi TOEFL yang berjalan, pertama Pendaftar datang ke kampus dan menemui Ketua Pelaksana untuk melakukan pendaftaran/registrasi, kemudian pendaftar melakukan pembayaran registrasi TOEFL dan memberikan fotocopy bukti pembayaran kepada ketua pelaksana, selanjutnya Pendaftar kembali menemui Ketua Pelaksana untuk mendiskusikan mengenai waktu pelaksanaan training, dan ketua pelaksana menentukan waktu pelaksanaan training peserta TOEFL. Berdasarkan rumusan masalah yang telah peneliti uraikan tersebut maka dapat disimpulkan beberapa permasalahan yang terangkum dalam rumusan masalah yaitu sebagai berikut :

1. Bagaimana cara yang digunakan agar proses Registrasi TOEFL (Test Of English Foreign Language) dapat dilakukan dan di akses secara online?

2. Bagaimana cara yang dapat digunakan agar user dapat mengetahui informasi jumlah pendaftar secara ringkas, cepat, dan akurat?

3. Apakah dengan adanya sistem registrasi toefl secara online proses registrasi TOEFL berjalan lebih efektif?

\section{Implementasi}

1. Tampilan halaman utama (home)

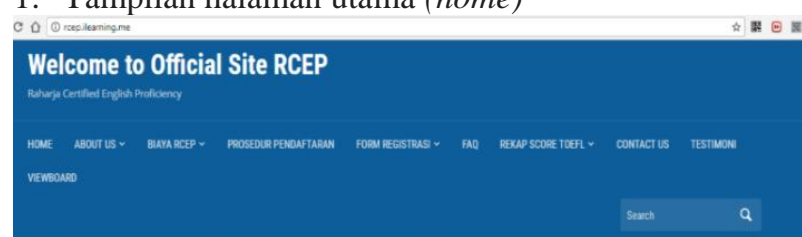

HOME
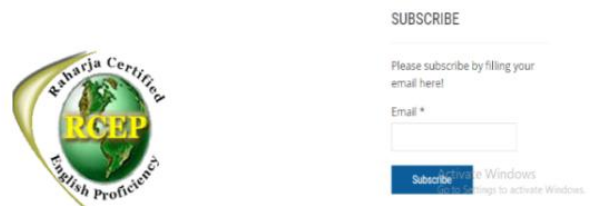

Gambar 6. Tampilan Home official site RCEP

Tampilan di atas merupakan halaman utama atau home dari official site RCEP. Pada halaman utama ini terdapat 5 (lima) widget dan 9 (sembilan) menu lainnya, yang dimana masing-masing ada yang memiliki sub menu.

2. Tampilan halaman formulir registrasi TOEFL

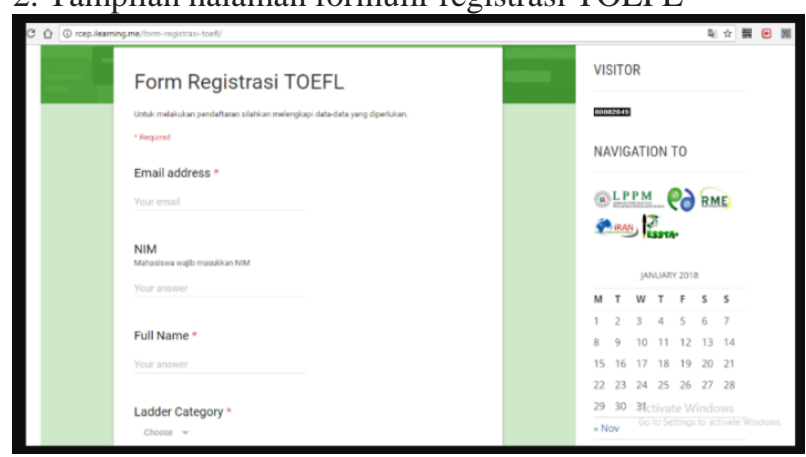

Gambar 7. Tampilan form registrasi toefl

Tampilan di atas merupakan formulir registrasi TOEFL, terdiri dari beberapa field dengan menggunakan bahasa inggris, dan pendaftar dapat mengisi data yang dibutuhkan untuk dapat mendaftarkan diri menjadi peserta training dan test TOEFL.

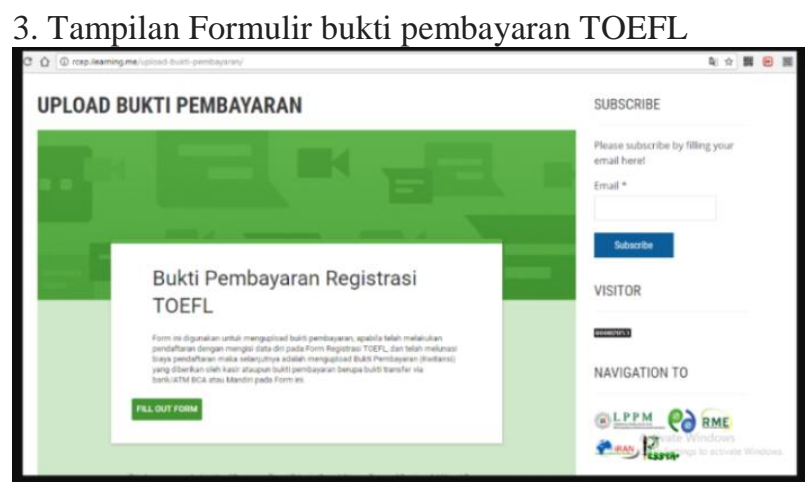

Gambar 8. Tampilan form bukti pembayaran TOEFL

Tampilan diatas merupakan bukti dari formulir pembayaran TOEFL, yang terdapat field upload agar responden dapat langsung mengupload bukti pembayaran pada wadah yang sudah disediakan. 


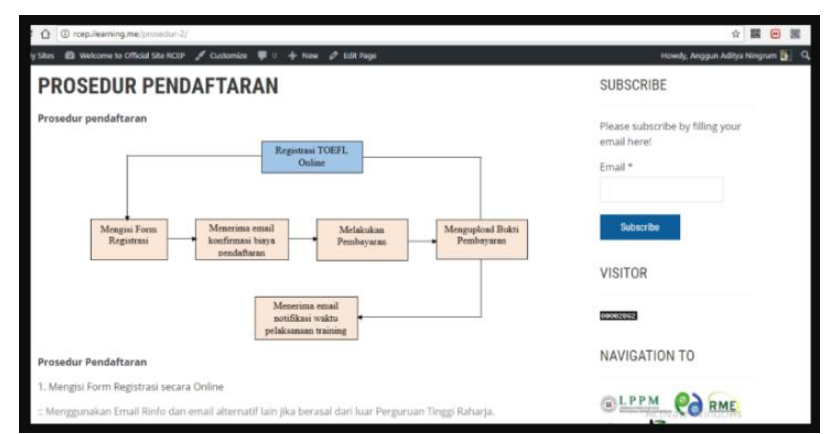

Gambar 9. Alur prosedur pendaftaran TOEFL

Tampilan diatas merupakan prosedur pendaftaran TOEFL dimana terdapat 5 (lima) alur dalam proses registrasi TOEFL secara online.

\section{Kesimpulan}

1. Dengan adanya sistem registrasi TOEFL secara online ini proses registrasi TOEFL yang ada di Perguruan Tinggi Raharja menjadi lebih efektif karena data dan informasi pendaftar yang diterima dapat tersimpan dengan baik di dalam Rinfo Spreadsheets tanpa takut akan kerusakan data dan hilang.

2. Dengan adanya data yang otomatis tersimpan dalam Rinfo Form dan Rinfo Spreadsheets pada saat responden telah mengisi form registrasi dan berhasil submit, maka penulis menarik data tersebut untuk kemudian diakumulasikan menjadi sebuah grafik yang menunjukkan jumlah data pendaftar setiap bulannya dalam bentuk viewboard official site $R C E P$. Viewboard ini dapat menyajikan sebuah informasi yang berkaitan dengan pelaksanaan dan hasil tes TOEFL secara ringkas, cepat, dan akurat.

\section{Saran}

1. Diperlukan adanya sosialisasi yang lebih kepada Pribadi Raharja agar sistem dapat benar-benar berjalan dengan maksimal dan tidak ada lagi Pribadi Raharja yang melakukan pendaftaran secara manual karena menggunakan form registrasi online yang telah tersedia.

2. Meningkatkan sosialisasi yang dapat dilakukan oleh berbagai sosial media agar sistem dapat berfokus pada TOEFL dapat dikenal oleh masyarakat luas, mengingat sasaran dari TOEFL RCEP ini bukan hanya mahasiswa dan dosen Perguruan Tinggi Raharja saja.

\section{Ucapan Terima Kasih}

Penulis mengucapkan terima kasih kepada Perguruan Tinggi Raharja yang telah memberikan dukungan penuh terhadap penelitian ini.

\section{Daftar Pustaka}

[1] Handayani, I., Kusumahati, H., Badriah, A. N, 2017, Pemanfaatan Google Spreadsheet Sebagai Media Pembuatan Dashboard Pada Official Site iFacility di Perguruan Tinggi, Jurnal SISFOTENIKA, No. 2, Vol. 7, Hal. 177-186.

[2] Pujastuti, E., 2016, Perancangan Sistem Informasi Pendaftaran Mahasiswa Aktif Kembali di STMIK Amikom Yogyakarta, Jurnal Dasi, No.2, Vol.17, Hal 31-37.

[3] Mentaruk, I. Y., Wenas, R. S., \& Jan, A. H. (2018). ANALISIS PENGARUH BUDAYA ORGANISASI, DISIPLIN KERJA DAN KOMUNIKASI TERHADAP KINERJA KARYAWAN (STUDI KASUS DI PT. ANGKASA PURA 1 (PERSERO) CABANG BANDARA INTERNASIONAL SAM RATULANGI MANADO). Jurnal EMBA: Jurnal Riset Ekonomi, Manajemen, Bisnis dan Akuntansi, 5(3).

[4] Agustin, A., Suryono, H., \& Yuliandari, E. (2017). TEKNIK PENILAIAN DIRI BERBASIS GOOGLE FORM PADA MATA PELAJARAN PENDIDIKAN PANCASILA DAN KEWARGANEGARAAN.

[5] Tileng, Kartika Gianina.2015. "Penerapan Technology Acceptance Model pada Aplikasi Edmodo di Universitas Ciputra Surabaya menggunakan Analisis Jalur".

[6] Rahardja Untung, Khanna Tiara, Ray Indra Taufik Wijaya.2014. 'Penerapan Rinfo Sebagai Media Pendukung Untuk Proses Pembelajaran Pada Perguruan Tinggi Raharja”. Vol. 8 No. 1 ISSN : 1978 - 8282.

[7] Fauzi, Muhammad Rizal.2014."Penggunaan Google Form Sebagai Alat Evaluasi Pembelajaran Pada Mata Pelajaran Bahasa Indonesia: Studi Deskriptif Analitis pada Kelas VIII di Sekolah Menengah Pertama Negeri 1 Lembang." 